\title{
Method of producing parboiled rice without steam by fluidized bed dryer
}

\author{
Asadayuth Mitsiri ${ }^{*}$, Somkiat Prachayawarakorn ${ }^{2}$, Sakamon Devahastin ${ }^{3}$, Wathanyoo \\ Rordprapat $^{4}$, and Somchart Soponronnarit ${ }^{1}$ \\ ${ }^{1}$ King Mongkut's University of Technology Thonburi (KMUTT), Division of Energy Technology, \\ 126 Pracha-Uthit Road, Bang Mod, Thungkhru, Bangkok 10140, Thailand \\ ${ }^{2}$ King Mongkut's University of Technology Thonburi (KMUTT), Department of Chemical \\ Engineering, 126 Pracha-Uthit Road, Bang Mod, Thungkhru, Bangkok 10140, Thailand \\ ${ }^{3}$ King Mongkut's University of Technology Thonburi (KMUTT), Department of Food Engineering, \\ 126 Pracha-Uthit Road, Bang Mod, Thungkhru, Bangkok 10140, Thailand \\ ${ }^{4}$ Rajamangala University of Technology Tawan-ok, Department of Energy Technology, 43 Moo 6 \\ Bangpra, Sriracha, Chinburi, 20110, Thailand
}

\begin{abstract}
A more simple methodology of producing parboiled rice is subject to be investigated in this work with proposed the method, the gelatinization of rice starch, commonly taking place at the steaming step in the traditional process, and drying are combined and replaced by a hot air fluidized bed dryer. A pilot-scale continuous fluidized bed, with a maximum capacity of $140-150 \mathrm{~kg} / \mathrm{h}$, has been designed, constructed and tested. Suphanburi 90 paddy variety with high amylose content was dipped into hot water at temperatures of $70,80,83^{\circ} \mathrm{C}$ for $4.0,3.3,3.2 \mathrm{~h}$, respectively, to get the moisture content around $47-55 \% \mathrm{db}$ and dried at $150-170^{\circ} \mathrm{C}$ using air speed of $3.5 \mathrm{~m} / \mathrm{s}$. The paddy bed depth within the dryer was 3 and $5 \mathrm{~cm}$. In the dryer operation, the exhaust air was fully recycled and reheated again by $30 \mathrm{~kW}$ electrical heaters to the desired temperature. The experimental result has shown that parboiled rice with a different degree of starch gelatinization could be produced by this technique. The degree ranged between $80-100 \%$ as examined by differential scanning calorimeter. The exit moisture content was given in a range of $14-21 \% \mathrm{db}$, relying on the drying temperature and soaking time. The aforementioned exit moisture contents were not a detrimental effect on head rice yield although the tempering was not included. The head rice yield was given in the range of 59-66\%, depending on the degree of starch gelatinization. The starch granules lost their original shape as revealed by scanning electron microscope.
\end{abstract}

\section{Introduction}

Rice parboiling is a method for prolonging rice and provides more nutritious values [1] such as more vitamins B and some minerals. To produce parboiled rice, it is necessary to pass the hydrothermal process.

* Corresponding author: asadayuth.m@hotmail.com 
The conventional hydrothermal process for parboiled rice consists of 3 main steps, soaking, steaming and drying. The soaking step is usually applied to enhance water diffusion into the kernel. It can make the starch granules swell. For steaming step, it is the main step for starch gelatinization. In addition, the rice starch during steaming can change its color from white to dark brown or light brown color [2-4]. The steaming step is important to parboiled rice quality. While the starch gelatinization is not yet complete, there normally appears white belly at the center of the kernel, which can break the kernel easily during milling [5]. In addition, the parboiling method involves high steam pressure and temperature to gelatinize rice starch. The steaming is normally performed at an absolute pressure of $199-248 \mathrm{kPa}$ and a corresponding steam temperature of $100-105^{\circ} \mathrm{C}$ for $15-30$ min [6]. The steaming modifies physico-chemical rice property, leading to easier dehusking, higher yield of full kernel and firm cooked rice texture [7, 8]. In modern parboiling technology, a superheated-steam fluidized-bed dryer can act as both a steamer and a dryer, and it can produce parboiled rice with a complete degree of starch gelatinization [9]. A hot-air microwave dryer can also apply the microwave to achieve gelatinization of rice starch. Microwaves are also used to get the gelatinized rice starch [10]. [11] studied the simultaneous parboiling and drying of rice using hot air fluidized bed technique and microwave assisted hot air fluidized bed. It was found that at initial moisture content of paddy $42 \pm 1 \% \mathrm{db}$ and the hot air temperature of $170^{\circ} \mathrm{C}$, paddy could achieve complete gelatinization, due to the feature of volumetric heating. Many studies focused on drying agricultural products [12] and a combination of microwave with hot air has shown significant improvement in operating cost and product quality [13], and has made parboiling process more efficient time [14-16].

As above-mentioned, the application of continuous fluidized bed for simultaneous parboiling and drying rice has not been officially reported. There is only one work carried out by lab scale. Therefore, this research studied parboiled rice production by reducing the steaming process and using a continuous fluidized bed dryer. The objective of work was to explore effect of soaking and drying temperature, bed depth on the quality of soaked paddy in terms of degree of starch gelatinization, head rice yield and starch morphology.

\section{Materials and methods}

\subsection{Material}

The experiment was done at the Agricultural Learning Center, Chonburi province, Thailand. Supanburi 90 paddy variety was harvested in January 2018 and had already been kept at the barn at ambient temperature for 1 month. The moisture content of the paddy during storage was about $11-12 \%$ d.b.

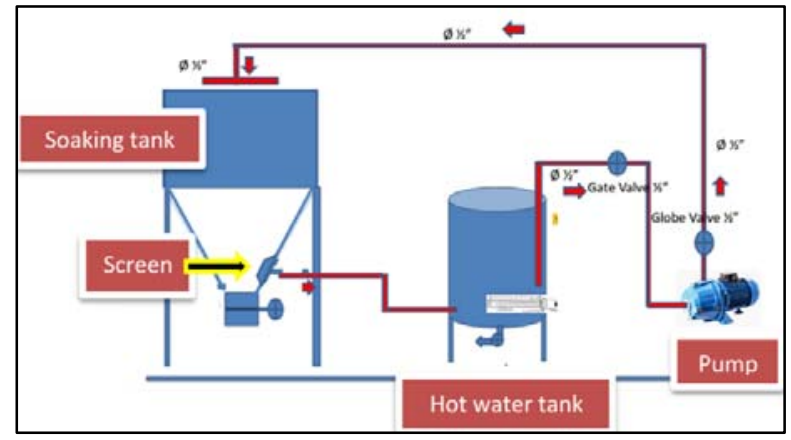

Fig. 1. Schematic diagram of soaking step. 


\subsection{The parboiled rice process}

In this work, the proposed process of parboiled rice consisted of soaking and drying.

\subsubsection{Soaking system}

Figure 1 shows a schematic diagram of the soaking system. The soaking system consisted of a soaking tank with a volume of $0.36 \mathrm{~m}^{3}$, a hot water tank, heaters and a pump. A screen in the soaking tank was used to prevent the paddy flowing out from the soaking tank. The water used for soaking paddy was heated by $6 \mathrm{~kW}$ heaters and the water was circulated by a 1 HP pump. The temperature of hot water was controlled by an on-off magnetic controller with an accuracy of $\pm 2^{\circ} \mathrm{C}$. Three K-type thermocouples were inserted into the water tank at 3 levels: bottom, middle and top of the soaking tank. The thermocouple at the top position was used to control the temperature of soaking water. As recorded from the soaking experiment, the temperature differences between the three positions were approximately $1{ }^{\circ} \mathrm{C}$.

\subsubsection{Fluidized bed drying system}

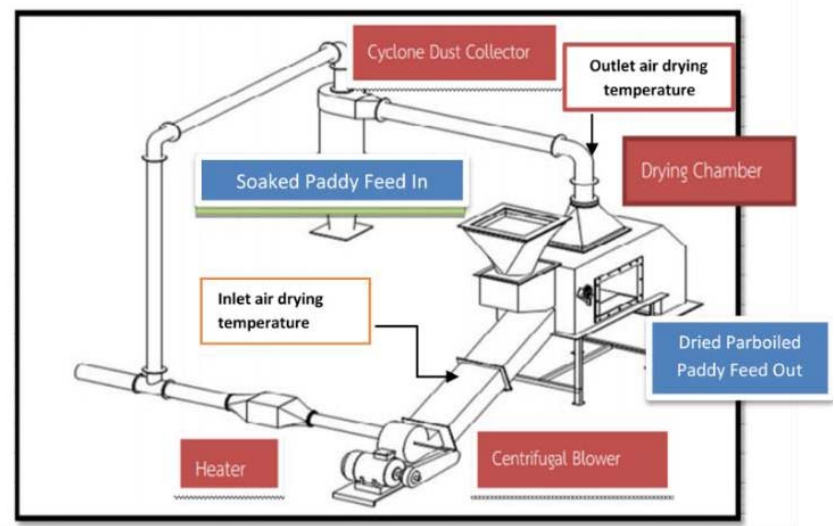

Fig. 2. Schematic diagram of a continuous fluidized bed system.

Figure 2 illustrates a diagram of a continuous fluidized bed system. The soaked paddy is moved in the cross direction of the air flow. The drying system consisted of $30 \mathrm{~kW}$ electrical heaters, a $4 \mathrm{Hp}$ centrifugal fan. The drying chamber had a volume of $0.176 \mathrm{~m}^{3}$. A cyclonic separator was used to collect the foreign materials. Hopper or feeder served as the transportation of the paddy into the drying chamber. The paddy moved through the drying chamber by gravity. In addition to the gravity, the paddy feed rate was regulated by adjusting position of valve near the inlet of drying chamber and the weir as shown in Figure 3.

\subsection{Method}

Paddy was dipped into the soaking tank at the water temperatures of $65,70,75,80$ and $83^{\circ} \mathrm{C}$ and soaked for 3.3, 4.0, 3.3, 3.3 and $3.2 \mathrm{~h}$, respectively. At these soaking times, about $1 \%$ of the kernels was split out from the endosperm. After soaking, the paddy was kept in a sack and the sack was laid tightly for preventing the moisture loss. The soaked paddy was finally dried by the continuous fluidized bed dryer. 


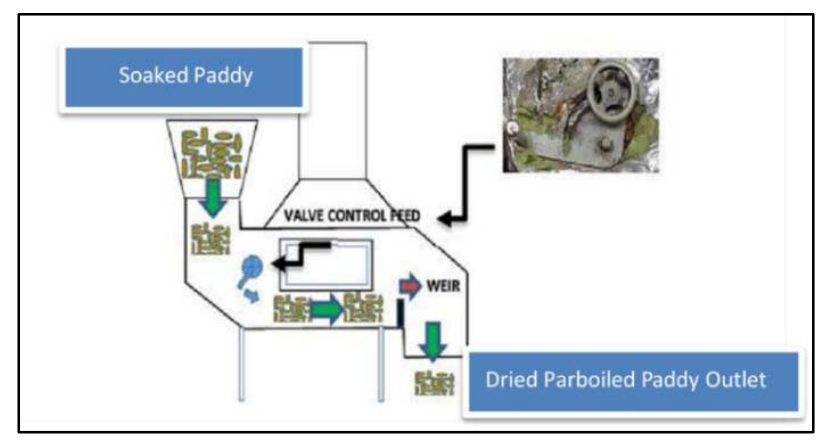

Fig. 3. Valve for controlling soaked paddy feed rate.

The drying experiments were done at the operating parameters of inlet drying temperatures of $130-170^{\circ} \mathrm{C}$ and a fixed velocity of $3.5 \mathrm{~m} / \mathrm{s}$ along with the bed depths of $3-5$ $\mathrm{cm}$. The air velocity used in this work was rather high than the common uses in the drying of paddy as reported by [17] since the paddy kernels are relatively cohesive at high moisture content. Prior to the experiment, the electrical heater and centrifugal fan were turned on and the desired drying temperature was controlled by the on-off magnetic controller with an accuracy of $\pm 2^{\circ} \mathrm{C}$. Two K-type thermocouples were used to monitor the inlet and outlet drying air temperatures, shown in Figure 2. When the drying temperature reached the desired value, the soaked paddy was fed into the drying chamber. The feed rate was in a range of $140-150 \mathrm{~kg}_{\text {wet paddy }} / \mathrm{h}$. The temperatures at the positions were recorded by a data logger (GL840 Graphtec Brand, Japan). Each dried paddy sample with $150 \mathrm{~g}$ was taken out at the drying chamber outlet every $10 \mathrm{~min}$ of the operation. The sample moisture content was determined by following the AACC method [18]. The samples obtained from the dryer exit still had moisture content in a range of $18-22 \% \mathrm{db}$, and thus the samples were ventilated by natural air until the moisture content arrived $13-15 \% \mathrm{db}$ and was finally kept in cold storage at $4-6^{\circ} \mathrm{C}$ until further quality analysis.

\subsection{Quality determination}

\subsubsection{Degree of starch of gelatinization}

Degree of starch gelatinization (DSG) was determined by the Differential Scanning Calorimeter (Perkin Elmer, model DSC-7, Newyork, USA). Dried paddy was de-husked by a hulling machine, ground and sieved by a 120 mesh screen. $3 \mathrm{mg}$ dried rice flour was put into an aluminum pan and mixed with $10 \mu \mathrm{L}$ distilled water after which it was sealed. After an hour [19], the sample was heated from 40 to $100^{\circ} \mathrm{C}$ at a rate of $10^{\circ} \mathrm{C} / \mathrm{min}$. The value of DSG was expressed by following equation:

$$
\mathrm{DSG}=\left[1-\frac{\Delta \mathrm{H}}{\Delta \mathrm{H}_{\mathrm{c}}}\right] \times 100
$$

where DSG is the degree of starch gelatinization (\%), $\Delta \mathrm{H}$ is the enthalpy change of the dried rice $\left(\mathrm{J} / \mathrm{g}\right.$ dry matter) and $\Delta \mathrm{H}_{\mathrm{C}}$ is the enthalpy change of raw rice. $(\mathrm{J} / \mathrm{g}$ dry matter) 


\subsubsection{Head rice yield (HRY)}

150 g paddy sample was de-husked by a rubber roller sheller (Ngeksenghuat, model P-1, Bangkok, Thailand) and milled by rice polisher (Ngeksenghuat, model K-1, Bangkok, Thailand) in 50 seconds for removing $8-10 \%$ rice brain after which it was sorted by a cylindrical separator to split milled rice between full and broken kernels. (Ngeksenghuat, model I-1, Bangkok, Thailand).

$$
\operatorname{HRY}(\%)=\frac{\text { Mass of full kernel of milled rice }}{\text { Mass of paddy }} \times 100
$$

\subsubsection{Scanning Electron Microscopy}

Microstructure of the dried rice was observed by a scanning electron microscope (model no. JS M-5410 LV, JEOL, Tokyo, Japan) with an acceleration voltage of $5 \mathrm{KV}$ and magnification level of 4000 . The sample was cut in a cross direction of the kernel, stuck by carbon adhesive tab and sputter-coated with gold. The samples were captured at the center of the kernel.

\section{Results and discussion}

\subsection{Effect of soaking temperature and soaking time}

Table 1. Effect of soaking temperature and duration degree of starch gelatinization.

\begin{tabular}{|c|c|c|c|c|c|c|c|}
\hline \multirow{2}{*}{$\begin{array}{c}\text { Soaking } \\
\text { Temperature } \\
{ }^{\circ} \mathrm{C}\end{array}$} & \multirow{2}{*}{$\begin{array}{c}\text { Soaking } \\
\text { Time } \\
\text { h } \\
\end{array}$} & \multirow{2}{*}{$\begin{array}{c}\text { Moisture } \\
\text { Content } \\
(\% \text { db) }\end{array}$} & \multicolumn{3}{|c|}{ Temperature } & \multirow[b]{2}{*}{$\begin{array}{c}\text { Enthalpy } \\
\text { J/g }\end{array}$} & \multirow{2}{*}{$\begin{array}{c}\text { DSG } \\
\%\end{array}$} \\
\hline & & & $\begin{array}{c}\text { Onset } \\
{ }^{\circ} \mathrm{C} \\
\end{array}$ & $\begin{array}{c}\text { Peak } \\
{ }^{\circ} \mathbf{C} \\
\end{array}$ & $\begin{array}{c}\text { End } \\
{ }^{\circ} \mathrm{C} \\
\end{array}$ & & \\
\hline Raw paddy & - & $11.0 \pm 0.9^{\mathrm{a}}$ & 72.1 & 76.3 & 79.6 & 4.77 & - \\
\hline 70 & 4.00 & $47.4 \pm 0.6^{\mathrm{b}}$ & 75.5 & 79.2 & 82.5 & $3.35 \pm 0.2$ & $29.77 \pm 0.9$ \\
\hline 75 & 3.30 & $48.5 \pm 3.2^{\mathrm{b}, \mathrm{c}}$ & 79.1 & 82.5 & 84.2 & $3.16 \pm 0.1$ & $33.73 \pm 0.3$ \\
\hline 80 & 3.30 & $50.9 \pm 0.7^{\mathrm{c}}$ & 79.3 & 83.3 & 85.9 & $3.09 \pm 0.4$ & $35.22 \pm 0.2$ \\
\hline 83 & 3.20 & $55.1 \pm 0.5^{\mathrm{d}}$ & 79.9 & 83.4 & 86.1 & $2.97 \pm 0.2$ & $37.74 \pm 0.3$ \\
\hline
\end{tabular}

$\overline{\mathrm{a}, \mathrm{b}, \mathrm{c}, \mathrm{d}}$ Different superscripts in the same column are significantly different at $\mathrm{p} \geq 0.05$.

Table 1 shows the effects of soaking temperature and soaking time on the value of DSG. The enthalpy of raw paddy for the Supanburi 90 was $4.77 \mathrm{~J} / \mathrm{g}$. After soaking, it was found that at the soaking temperature of $70^{\circ} \mathrm{C}$ and the time of $4.00 \mathrm{~h}$, the moisture content was $47.4 \pm 0.6 \% \mathrm{db}$ When the water temperature increased to $75^{\circ} \mathrm{C}$ and the time of $3.30 \mathrm{~h}$, the moisture content was $48.5 \% \mathrm{db}$, there was no significant difference as compare to that at $70^{\circ} \mathrm{C}$ and $4.00 \mathrm{~h}$. When temperature was increased to $80^{\circ} \mathrm{C}$ and the time of $3.30 \mathrm{~h}$, the moisture content was $50.9 \% \mathrm{db}$. As the soaking, it showed a significant difference. The higher initial moisture content at higher soaking temperature indicated that the soaking temperature is an important parameter to accelerate water movement [21]. In addition to the faster movement of moisture at higher soaking temperature, the soaking temperature caused starch to be gelatinized with a certain degree. The higher degree was found at the soaking temperature of $80-83^{\circ} \mathrm{C}$. 
Table 2. Effects of soaking temperature and drying temperature on gelatinization.

\begin{tabular}{|c|c|c|c|c|c|c|}
\hline $\begin{array}{c}\text { Sample Temperature } \\
\left({ }^{\circ} \mathrm{C}\right)\end{array}$ & $\begin{array}{c}\text { Bed } \\
\text { depth } \\
(\mathbf{c m})\end{array}$ & $\begin{array}{l}\text { Feed } \\
\text { Rate } \\
(\mathrm{kg} / \mathrm{h})\end{array}$ & $\begin{array}{c}\text { Initial moisture } \\
\text { Content } \\
(\% \text { db) }\end{array}$ & $\begin{array}{c}\text { Final moisture } \\
\text { Content } \\
(\% \mathrm{db})\end{array}$ & $\begin{array}{c}\text { Exit } \\
\text { Grain } \\
\text { Temp }\left({ }^{\circ} \mathrm{C}\right)\end{array}$ & $\begin{array}{c}\text { DSG } \\
(\%)\end{array}$ \\
\hline \multicolumn{7}{|c|}{ Soaking $70^{\circ} \mathrm{C}$ Time $4.00 \mathrm{~h}$} \\
\hline \multicolumn{7}{|c|}{ Dried Parboiled Paddy } \\
\hline 150 & 3 & 147.47 & $47.7 \pm 0.3$ & $21.0 \pm 0.4$ & 91 & $80.78 \pm 0.3$ \\
\hline 160 & 5 & 139.45 & $47.4 \pm 0.8$ & $16.8 \pm 0.6$ & 98 & $93.47 \pm 0.1$ \\
\hline 160 & 3 & 141.60 & $47.7 \pm 0.3$ & $20.5 \pm 0.4$ & 94 & $92.01 \pm 0.5$ \\
\hline 170 & 5 & 142.31 & $47.7 \pm 0.3$ & $14.4 \pm 0.7$ & 104 & $100.00 \pm 0.0$ \\
\hline \multicolumn{7}{|c|}{ Soaking $80^{\circ} \mathrm{C}$ Time $3.30 \mathrm{~h}$} \\
\hline \multicolumn{7}{|c|}{ Dried Parboiled Paddy } \\
\hline 150 & 3 & 148.35 & $50.0 \pm 0.3$ & $17.4 \pm 0.8$ & 103 & $100.00 \pm 0.0$ \\
\hline 150 & 5 & 152.45 & $50.0 \pm 0.3$ & $15.9 \pm 0.4$ & 112 & $100.00 \pm 0.0$ \\
\hline 160 & 3 & 140.25 & $50.9 \pm 0.5$ & $16.4 \pm 0.3$ & 110 & $100.00 \pm 0.0$ \\
\hline \multicolumn{7}{|c|}{ Soaking $83 \mathrm{C}$ Time $3.20 \mathrm{~h}$} \\
\hline $\begin{array}{c}\text { Dried Parboiled Paddy } \\
\qquad 150\end{array}$ & 2 & 14065 & $551+04$ & $216+06$ & 100 & م \\
\hline
\end{tabular}

Table 2 presents the effect of the combination of soaking and drying temperatures on the value DSG. It was found that at the soaking temperature of $70^{\circ} \mathrm{C}$ and soaking time of $4.00 \mathrm{~h}$, the starch gelatinization was incompletely gelatinized at the drying temperature $150-160^{\circ} \mathrm{C}$, the value of DSG between 80 and $93 \%$. As the drying temperature was increased to $170^{\circ} \mathrm{C}$ and bed depth of $5 \mathrm{~cm}$, the starch gelatinization was completed. However, as the soaking temperature was increased to $80^{\circ} \mathrm{C}$ and soaking time of $3.3 \mathrm{~h}$, or $83^{\circ} \mathrm{C}$ and $3.2 \mathrm{~h}$, the complete starch gelatinization could be achieved at the $150^{\circ} \mathrm{C}$ for both bed depths of 3 and $5 \mathrm{~cm}$.

\subsection{Head rice yield}

Table 3. Effect of processing conditions on head rice yield.

\begin{tabular}{|c|c|c|c|c|c|c|}
\hline Sample & $\begin{array}{c}\text { Temperature } \\
\left({ }^{\circ} \mathrm{C}\right)\end{array}$ & $\begin{array}{c}\text { Bed } \\
\text { depth } \\
\text { (cm) }\end{array}$ & $\begin{array}{c}\text { Exit Grain } \\
\text { Temp } \\
\left({ }^{\circ} \mathrm{C}\right)\end{array}$ & $\begin{array}{c}\text { Final moisture } \\
\text { Content } \\
(\% \text { db) }\end{array}$ & $\begin{array}{c}\text { DSG } \\
(\%)\end{array}$ & $\begin{array}{l}\text { Head rice } \\
\text { yield (\%) }\end{array}$ \\
\hline \multicolumn{7}{|c|}{ Soaking $70^{\circ} \mathrm{C}$ Time $4.00 \mathrm{~h}$} \\
\hline & 150 & 3 & 93 & $21.0 \pm 0.4$ & $80.78 \pm 0.3$ & $59.34 \pm 1.06^{\mathrm{a}}$ \\
\hline & 160 & 5 & 98 & $16.8 \pm 0.6$ & $93.47 \pm 0.1$ & $65.03 \pm 1.09^{b, c}$ \\
\hline & 160 & 3 & 94 & $20.5 \pm 0.4$ & $92.01 \pm 0.5$ & $64.40 \pm 0.48^{\mathrm{b}}$ \\
\hline & 170 & 5 & 104 & $14.4 \pm 0.7$ & $100.00 \pm 0.0$ & $66.61 \pm 0.46^{\mathrm{d}}$ \\
\hline \multicolumn{7}{|c|}{ Soaking $80^{\circ} \mathrm{C}$ Time $3.30 \mathrm{~h}$} \\
\hline \multicolumn{7}{|c|}{ Dried Parboiled Paddy } \\
\hline & 150 & 3 & 103 & $17.4 \pm 0.8$ & $100.00 \pm 0.0$ & $66.44 \pm 0.35^{\mathrm{c}, \mathrm{d}}$ \\
\hline & 150 & 5 & 112 & $15.9 \pm 0.4$ & $100.00 \pm 0.0$ & $66.25 \pm 0.05^{\mathrm{c}, \mathrm{d}}$ \\
\hline & 160 & 3 & 110 & $16.4 \pm 0.3$ & $100.00 \pm 0.0$ & $66.19 \pm 0.23^{\mathrm{c}, \mathrm{d}}$ \\
\hline \multicolumn{7}{|c|}{ Soaking $83 \mathrm{C}$ Time $3.20 \mathrm{~h}$} \\
\hline \multicolumn{7}{|c|}{ Dried Parboiled Paddy } \\
\hline & 150 & 3 & 100 & $21.6 \pm 0.6$ & $100.00 \pm 0.0$ & $66.65 \pm 0.39^{\mathrm{c}, \mathrm{d}}$ \\
\hline
\end{tabular}

Table 3 shows the head rice yield of dried samples at different processing conditions. The yield improvement depended on the degree of gelatinization. The head rice yield was increased from $59 \%$ to $65 \%$, as the value of DSG was increased from 80 to $93 \%$ at the 
soaking temperature of $70^{\circ} \mathrm{C}$. When the drying temperature was increased until complete gelatinization, the HRY was insignificantly different.

\subsection{Scanning electron microscopy}

Figure 4 shows the microstructure of rice before and after drying at different processing conditions and all pictures showed the starch morphologies at the center kernel. The size of starch granule of raw paddy was about $4.3 \pm 1.2 \mu \mathrm{m}$ as shown in Figure 4(a). After soaking, it seems that starch still appeared as shown in Figure 4(b). After drying, the starch granule characteristics of the dried rice kernel were different from those of the raw and soaked kernels. The polygonal starch granule shape was less defined and some starch granules were disrupted as shown in Figure 4(c) - (i).
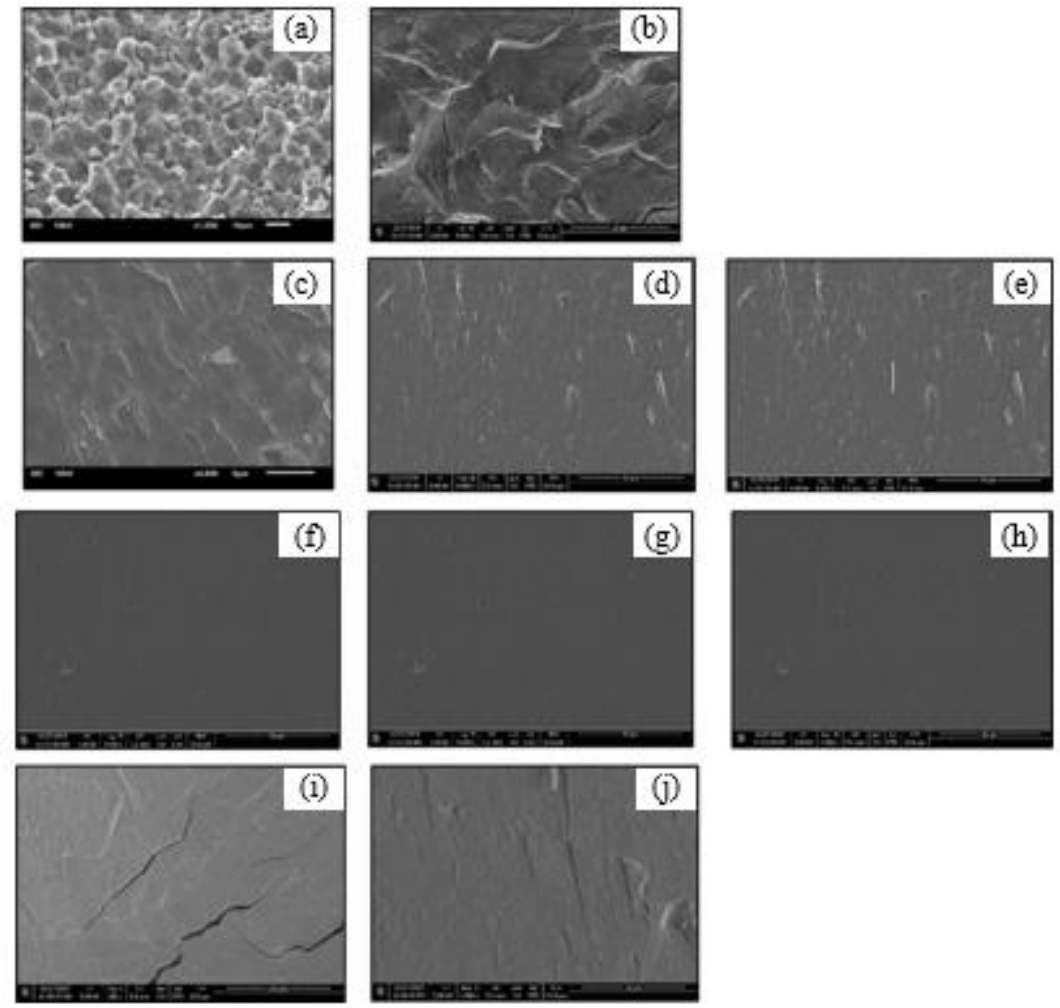

Figure 4. SEM micrographs: Raw paddy (a) Soaked paddy, (b) Soaking $70^{\circ} \mathrm{C}$ and time $4.00 \mathrm{~h}$, (c) $\mathrm{T} 150^{\circ} \mathrm{C}$ and bed depth $3 \mathrm{~cm},(\mathrm{~d}) \mathrm{T} 160^{\circ} \mathrm{C}$ and bed depth $5 \mathrm{~cm}$, (e) $\mathrm{T} 160^{\circ} \mathrm{C}$ and bed depth $3 \mathrm{~cm}$, (f) $\mathrm{T} 170^{\circ} \mathrm{C}$ and bed depth $5 \mathrm{~cm}$ Soaking $80^{\circ} \mathrm{C}$ and time $3.30 \mathrm{~h},(\mathrm{~g}) \mathrm{T} 150^{\circ} \mathrm{C}$ and bed depth $3 \mathrm{~cm}$, (h) $\mathrm{T} 150^{\circ} \mathrm{C}$ and bed depth $5 \mathrm{~cm}$, (i) $\mathrm{T} 160^{\circ} \mathrm{C}$ and bed depth $3 \mathrm{~cm}$ Soaking $83^{\circ} \mathrm{C}$ and time $3.20 \mathrm{~h},(\mathrm{j})$ $\mathrm{T} 150^{\circ} \mathrm{C}$ and bed depth $3 \mathrm{~cm}$. 


\section{Conclusions}

From this study, it was found that the production of parboiled rice without steam has a good tendency. For the level of gelatinization, it was found that gelatinization could occurred during soaking with a level between 23 and 38\% depending on soaking temperature and soaking time. After drying, the DSG was increased with increasing temperature and drying time. The drying temperature of $150^{\circ} \mathrm{C}$, soaking temperature $80^{\circ} \mathrm{C}$ and time $3.3 \mathrm{~h}$ could produce parboiled rice with a complete degree. The quality of HRY was related to the DSG value.

This work was supported by Thailand Research Fund (Grant no. DPG 5980004 and RGU 6180004 and RTA 5880009). Also, thanks to the learning center for increasing agricultural production efficiency for providing material and location for testing pilot scale fluidized bed.

\section{References}

1. O. Chukwu, F.J. Oseh, AEJSA, 3(3), 381-387 (2009)

2. S.L. Bor, R.M. Robert, Rice, 2 (Van Nostrand Reinhold, New York, 1991)

3. S. Bhattachaya, J. Food Eng., 29(1), 99-106 (1996)

4. L. Lamberts, I. Rombouts, K. Brijs, K. Gebruers, J.A. Delcour, Food Chem., 110(4), 916-922 (2008)

5. N. Sitachitta, O. Naivikul, Lab scaling of parboiled rice process, in Proceedings of 41st Kasetsart University Annual Conference, 3-7 Feb 2003, Bangkok, Thailand (2003)

6. T. Adhikaritanayake, B. Noomhorm, J. Food Eng., 36, 135-143 (1998)

7. F. Gariboldi, Parboiled rice (St. Paul, MN, 1972)

8. K.R., Bhattacharya, Parboiling of rice (St. Paul, MN, 1995)

9. W. Rordprapat, A. Nathakaranule, W. Tia, S. Soponronarit, J. Food Eng., 71(1), 28-36 (2005)

10. G. Behera, P.P. Sutar, Trends Food Sci Tech, 75, 206-230 (2018)

11. E. Saniso, S. Prachayawarakorn, T. Swasdisewi, S. Soponronnarit, Effect of a combined microwave and fluidized bed drying on drying kinetics and qualities of the parboiled rice, in Proceeding of the 17th TSAE National Conference and the 9th TSAE International Conference, 8-10 Sep 2016, Bangkok, Thailand (2016)

12. M. Zhang, J. Tang, A.S. Mujumbar, S. Wang, Trends Food Sci Tech, 17, 524-534 (2006)

13. E.I. Goksu, G. Sumnu, A. Esin, J. Food Eng., 66, 463-468 (2005)

14. K. Cheenkachorn, Drying of rice paddy using a microwave vacuum dryer, in Proceedings of European Congress of Chemical Engineering, 16-20 Sep 2007, Copenhagen, Denmark (2007)

15. C. Sangdao, M. Krairiksh, Electric field and temperature distributions of a continuous fluidized bed microwave paddy drying system, in Proceeding of 20th Asia-Pacific Microwave Conference, APMC, 16-20 Dec 2008, Hong Kong (2008)

16. M. Fofana, J. Wanvoeke, J. Manful, K. Futakuchi, P.V. Mele, E. Zossou, T.M.R. Bleoussi, Int. Food Res. J., 18, 715-721 (2011)

17. S. Soponronnarit, S. Prachayawarakorn, Dry Technol, 12(7), 1667-1686 (1994)

18. AACC, Approved method of the AACC (St. Paul, MN, 1995) 
19. W. Marshall, J.I. Wadsworth, L.R. Verma, L. Velupillai, Cereal Chem., 70, 226-230 (1993)

20. P. Jaiboon, S. Prachayawarakorn, S. Devahastin, S. Soponronnarit, J. Food Eng., 95, 517-524 (2009)

21. S.J. Kale, S.K. Jha, G.K. Jha, J.P. Sinha, S.B. Lal, Rice Sci., 22(5), 227-236 (2015) 